\title{
Effect of Gamma Irradiation Combined with Certain Entomopathogenic Fungi on some Biological Aspects of Galleria mellonella
}

Hussein Farid Mohamed ( $\nabla$ husseinmohamed29@yahoo.com )

Egyptian Atomic Energy Authority https://orcid.org/0000-0002-3289-8383

\section{Samira Elsayed Mustafa El-Naggar}

Egyptian Atomic Energy Authority

Mahmoud Abd El-Mohsen Sweilem

Benha University Faculty of Science

Adly Mohamed Ibrahim

ARC Plant Protection Research Institute

Ola Elsayed Abd Alrahman El-khawaga

EAEA: Egyptian Atomic Energy Authority

\section{Research Article}

Keywords: Entomopathogenic Fungi, Galleria mellonella, Gamma Irradiation

Posted Date: March 3rd, 2022

DOI: https://doi.org/10.21203/rs.3.rs-1209892/v1

License: (c) (i) This work is licensed under a Creative Commons Attribution 4.0 International License. Read Full License 


\section{Abstract}

Background: the prevailing research become analyzing the impact of the one-of-a-kind doses of gamma irradiation

$(70,100,125$ and $150 \mathrm{~Gy})$ one after the other or mixed with the $\mathrm{LC}_{50}$ of certain entomopathogenic fungi (Beauveria bassiana, Paecilomyces lilacinus) on selected biological aspects of the greater wax moth, Galleria mellonella (larvalpupal period, The percentage pupation, The percentage adult emergence, sex ratio and The percentage adult survival) many of the first generations $\left(\mathrm{F}_{1}\right)$ of $G$. mellonella.

Results: The joint treatment of Gamma irradiation and $\mathrm{LC}_{50}$ of Beauveria bassiana and Paecilomyces lilacinus increased the larval - pupal periods, while, pupation, adult emergence, survival percentage and the sex ratio were reduced in the combined treatments more than each treatment alone.

Conclusions: The second instar larvae of Galleria mellonella descending of the irradiated parental male or female pupae with 70,100 and $125 \mathrm{~Gy}$ then treated with the $\mathrm{LC}_{50}$ of Beauveria bassiana and Paecilomyces lilacinus adversely affected on the different biological aspects. The combined treatment was greater than either, in the case of fungal or irradiation treatment alone.

\section{Background}

The greater wax moth (GWM), Galleria mellonella L. (Lepidoptera: Pyralidae) is one of the most disturbing and economically important pests of wax in the world (Chang and Hsieh 1992, Haewoon et al.1995, Hussein et al.2018).

This insect feeds on comb wax in the larval stage and damages it severely. The larvae of the wax moth, cause extensive damage to combs left unattended by bees. Combs in weak or dead colonies and storage areas are subject to attack (Caron 1992) .

Many researchers have focused on the selection of virulent strains for target pests and their development as biological control agents (Abd EL-Wahed 2011, Ibrahim et al. 2016, Nazir et al. 2019).

Entomopathogenic fungi that infect insects have received considerable attention from scientists for their potential for biological control of pests. Some insect pathogenic fungi have restricted host ranges while other fungal species have a wide host range, for example, Beauveria bassiana and Paecilomyces lilacinus.

Gamma irradiation increased the pathogenicity of the fungi against the tested larvae. The combination of the two control tools may provide satisfactory control of the insect pest, especially, in the storage (Mohamed et al. 2018).

The aim of the current work, study the effect of gamma irradiation in combination with $\mathrm{LC}_{50}$ of entomopathogenic fungi on some biological aspects of the $2^{\text {nd }}$ instar larvae of Galleria mellonella (L.)

\section{Methods}

\section{Insect rearing and irradiation process}

The greater wax moth, G. mellonella larvae were obtained from infested hives and reared in the Nuclear Research Center (NRC), Egyptian Atomic Energy Authority (EAEA), Egypt, Anshas area, the bio-insecticide Production Unit, Plant Protection Research Institute, Agricultural Research Center, Giza, Egypt. G. mellonella larvae reared on the an artificial diet at a constant temperature of $30^{\circ} \mathrm{C}$ and $65 \pm 5 \%$ relative humidity (R.H) according to (Metwally et al. 2012). The irradiation process was performed using cobalt-60 gamma cell 220 located at Cyclotron project, Nuclear Research Centre, Atomic 
Energy Authority (Anshas). The dose rate was $0.926 \mathrm{kGy} /$ hour during the experiment. Full-grown pupae of $G$. mellonella were exposed to four doses $70,100,125$, and $150 \mathrm{~Gy}$ to study the effect of irradiation on some biological aspects of $F_{1}$ progeny descendant of irradiated parental male and female pupae.

Ten larvae resulting from irradiated parental males and females and transferred to clean small plastic containers and allowed to feed on an artificial diet, each treatment was replicated five times. Dead larvae were counted. The larval and pupal period, pupation, adult emergence, sex ratio, Adult survival percentage, and the resulting progeny $\left(\mathrm{F}_{1}\right)$ were determined as well.

\section{Isolation of the Entomopathogenic Fungi}

The entomopathogenic fungal, Paecilomyces lilacinus isolates from soils and the entomopathogenic fungal, Beauveria bassiana isolates from dead insects (Ibrahim et al. 2016, El-khawaga 2017).

\section{The Latent Effect of the Investigated Entomopathogenic Fungi on Some Biological Aspects of G. Mellonella}

According to the high mortality percentage; $\boldsymbol{B}$. bassiana and $\boldsymbol{P}$. lilacinus were used in the determination of biological activity. The concentrations required to kill $50 \%$ of larvae during the observation period $\left(\mathrm{LC}_{50}\right)$ were chosen to study the effect of entomopathogenic fungi on some biological aspects (Table 1).

To evaluate the biological activity of $G$. mellonella under laboratory conditions, four replicates of the $2^{\text {nd }}$ instar larvae (20 larvae for each) were dipped into $9 \mathrm{ml}$ of $\mathrm{LC}_{50}$ of the tested entomopathogenic fungi (B. bassiana and P.Iilacinus) for 30 seconds. Then treated larvae were placed individually in small plastic containers and allowed to feed on the semisynthetic diet. For the control treatment, larvae were dipped into $0.02 \%$ Triton X-100 solution Dead larvae were counted daily. Growth parameters, namely larval - pupal period, pupation, adult emergence, sex ratio and survival (\%) were recorded.

Table 1 Virulence of fungal isolates against $2^{\text {nd }}$ instar larvae of G. mellonella*

\begin{tabular}{|llllll|}
\hline Fungal isolates & $\mathrm{Lc}_{50}$ conidia/ml & $\mathrm{Lc} \mathrm{c}_{95}$ & slope & $\mathrm{X}^{2}$ & $\mathrm{P}$ value \\
& & conidia/ml & & \\
\hline Beauveria bassiana & $1.2 \times 10^{5}$ & $1.9 \times 10^{8}$ & $0.2620 \pm 0.0305$ & 13.15 & 0.001 \\
\hline Paecilomyces lilacinus & $2.3 \times 10^{5}$ & $4.3 \times 10^{11}$ & $0.2064 \pm 0.0299$ & 04.30 & 0.120 \\
\hline
\end{tabular}

* expressed as the $\mathrm{LC}_{50}, \mathrm{LC}_{95}$, and slope of toxicity regression lines after 10 days of dipping in different concentration

\section{Combined Effect of Gamma Irradiation and Entomopathogenic Fungi on Some Biological Aspects of G. mellonella}

Three dose levels of gamma irradiation $(70,100,125)$ were chosen to study the combined effect of gamma irradiation with the ( $\mathrm{LC}_{50}$ ) of different entomopathogenic fungi (B. bassiana and P.lilacinus) on some biological aspects.

For studying the effects on some biological aspects of $\mathbf{G}$. mellonella, three experimental groups were set up. The first group consisted of the progeny of $F_{1}$ larvae descendants of the irradiated parental females as full-grown pupae with the three doses; 70,100 and 125Gy. The second group consisted of the progeny of $F_{1}$ larvae descendant of the irradiated 
parental males as full-grown pupae with the three doses; 70,100 and 125Gy. The third group was used as a parallel group of unirradiated insects; males and females were used as a control.

The progeny of $F_{1}$ larvae of each group were fed on an artificial diet till the $2^{\text {nd }}$ instar larvae, five replicates from the $2^{\text {nd }}$ instar larvae (10 larvae each) were dipped into $9 \mathrm{ml}$ of $\mathrm{LC}_{50}$ of the tested entomopathogenic fungi (B. bassiana and $\boldsymbol{P}$. lilacinus) for 30 seconds) in clean small plastic containers fitted with moist filter paper and allowed to feed on an artificial diet under laboratory condition $\left(28 \pm 2^{\circ} \mathrm{C}\right.$ and $65 \pm 5 \%$ relative humidity). Larval and pupal period, the percentage pupation, the percentage of adult emergence, sex ratio and the percentage of adult survival were determined.

\section{Statistical analysis}

The lethal concentration 50 was determined for established regression lines. All data obtained were analyzed using the Analysis of Variance (ANOVA) technique and the means were separated using Duncan's multiple range test $(P>0.05)$ (Steel and Torrie 1980)

\section{Results}

Table 1, Evaluated the Virulence of fungal isolates against $2^{\text {nd }}$ instar larvae of $G$. mellonella expressed as the $\mathrm{LC}_{50}, \mathrm{LC}_{95}$, and slope of toxicity regression lines after 10 days of dipping in different concentration (Methods)

The latent effect of gamma irradiation on some biological aspects of $F_{1}$ progeny descendant of irradiated parental males as full-grown pupae

Table 2, shows the effect of gamma irradiation on the larval and pupal period, the percentage pupation, the percentage of emergence, the sex ratio and the percentage survival of $\boldsymbol{G}$. mellonella among $\mathrm{F}_{1}$ male descendants of irradiated parental males as full-grown pupae with four doses 70,100,125 and 150 gray. The average larval and pupal period significantly increases with the dose increase. It increases to 41.73, $44.72,45.80$ and 47 days at the four doses, respectively, compared to 35.25 days for the control treatment.

There was a negative correlation between the percentage of pupation and the increase of doses. The percentage of pupation significantly decreases to 78, 74, 68 and $60 \%$ at the four doses $70,100,125$ and 150Gy respectively, compared to $92 \%$ for the control treatment (Table 2) while the percentage of the adult emergence of the $F_{1}$ generation was significantly decreased at all treatments. It decreases to 82.69, 80.71, 70.23 and $56.76 \%$ at the four doses 70, 100, 125 and 150 Gy respectively, compared to $93.55 \%$ for the control treatment (Table 2).

Table 2 Effect of gamma irradiation on the progeny of the greater wax moth, Galleria mellonella 


\begin{tabular}{|c|c|c|c|c|c|c|}
\hline \multirow[t]{2}{*}{$\begin{array}{c}\text { Doses } \\
\text { (Gy) }\end{array}$} & \multirow{2}{*}{$\begin{array}{l}\text { Larval and pupal } \\
\text { period/day } \\
\quad \pm \mathrm{SE}\end{array}$} & \multirow[t]{2}{*}{$\begin{array}{c}\text { \%pupation } \\
\text { 土SE }\end{array}$} & \multirow{2}{*}{$\begin{array}{c}\% \\
\text { Emergence } \\
\pm \mathrm{SE}\end{array}$} & \multicolumn{2}{|c|}{$\begin{array}{c}\text { Sex ratio } \\
\quad \pm \mathrm{SE}\end{array}$} & \multirow{2}{*}{$\begin{array}{c}\% \\
\text { survival } \\
\pm \mathrm{SE}\end{array}$} \\
\hline & & & & male & female & \\
\hline Control & $35.25 \pm 0.59 \quad \mathbf{d}$ & $92 \pm 3.75 a$ & $93.55 \pm 2.64 \mathbf{a}$ & $\begin{array}{l}1.18 \pm 0.13 \\
\mathrm{a}\end{array}$ & 1 & $\begin{array}{r}86 \pm \\
4.01 \mathrm{a}\end{array}$ \\
\hline 70 & $41.73 \pm 0.71 \quad \mathbf{c}$ & $\begin{array}{l}78 \pm 3.17 \\
\mathbf{b}\end{array}$ & $\begin{array}{l}82.69 \pm 2.64 \\
\mathbf{b}\end{array}$ & $\begin{array}{l}1.20 \pm 0.08 \\
\mathbf{a}\end{array}$ & 1 & $\begin{array}{c}66 \pm \\
2.45 \mathbf{b}\end{array}$ \\
\hline 100 & $44.72 \pm 0.26 \mathbf{b}$ & $\begin{array}{l}74 \pm 2.45 \\
\text { bc }\end{array}$ & $\begin{array}{l}80.71 \pm 3.81 \\
\mathbf{b}\end{array}$ & $\begin{array}{l}1.33 \pm 0.09 \\
\mathbf{a}\end{array}$ & 1 & $\begin{array}{r}60 \pm \\
4.48 \mathrm{~b}\end{array}$ \\
\hline 125 & $45.80 \pm 0.65 \mathrm{ab}$ & $\begin{array}{l}68 \pm 3.75 \\
\text { cd }\end{array}$ & $\begin{array}{l}70.23 \pm 1.60 \\
\text { c }\end{array}$ & $\begin{array}{l}1.40 \pm 0.18 \\
\mathbf{a}\end{array}$ & 1 & $\begin{array}{r}48 \pm \\
3.75 \mathrm{c}\end{array}$ \\
\hline 150 & $47.00 \pm 0.28 \mathbf{a}$ & $\frac{60}{\mathrm{~d}} \pm 3.17$ & $\begin{array}{l}56.76 \pm \\
3.17 \mathrm{~d}\end{array}$ & $\begin{array}{l}1.60 \pm 0.24 \\
\text { a }\end{array}$ & 1 & $\begin{array}{c}34 \pm \\
2.45 \mathrm{~d}\end{array}$ \\
\hline LSD 0.05 & 1.73 & 9.69 & 8.44 & 0.47 & & 10.38 \\
\hline
\end{tabular}

*Means followed by the same letter in each column (small letters) represent that are not significantly different at $(\mathrm{p}<0.05)$

*The progeny among $\mathrm{F}_{1}$ males of the greater wax moth, Galleria mellonella descending of the irradiated parental males as full-grown pupae

Table 2 also, displays that the average sex ratio was increased with the dose increase. It increases to 1.20 , $1.33,1.40$ and 1.60 at the four doses $70,100,125$ and $150 \mathrm{~Gy}$ respectively, compared to 1.18 for the control treatment.

Additionally, the percentage of larvae that survived to the adult stage (Table 2) was significantly decreased with the dose increase. The percentage of survival was decreased to 66, 60, 48 and 34 at the four doses 70, 100,125 and 150Gy respectively, compared to $86 \%$ for the control treatment.

Table 3 shows the $\mathrm{P}_{1}$ females irradiated as full-grown pupae with 70,100,125and 150 Gy then mated with a non-irradiated males. We observed that the parental females, which irradiated with the dose 150 Gy were, did not give any progeny.

The average larval and pupal period significantly increases with the dose increase. It increases to 42.27, 44.41 and 46.26 days at the three doses, respectively, compared to 35.25 days for the control treatment (Table 3).

Table 3 Effect of gamma irradiation on the progeny of the greater wax moth, Galleria mellonella 


\begin{tabular}{|c|c|c|c|c|c|c|}
\hline \multirow[t]{2}{*}{$\begin{array}{c}\text { Doses } \\
\text { (Gy) }\end{array}$} & \multirow{2}{*}{$\begin{array}{l}\text { Larval and pupal } \\
\text { period } \\
\quad \pm \mathrm{SE}\end{array}$} & \multirow[t]{2}{*}{$\begin{array}{c}\text { \%pupation } \\
\quad \pm \mathrm{SE}\end{array}$} & \multirow{2}{*}{$\begin{array}{c}\% \\
\text { Emergence } \\
\pm \mathrm{SE}\end{array}$} & \multicolumn{2}{|c|}{$\begin{array}{l}\text { Sex ratio } \\
\quad \pm \mathrm{SE}\end{array}$} & \multirow{2}{*}{$\begin{array}{c}\% \\
\text { survival } \\
\pm \mathrm{SE}\end{array}$} \\
\hline & & & & male & female & \\
\hline Control & $35.25 \pm 0.59 \quad \mathbf{c}$ & $\begin{array}{l}92 \pm 3.75 \\
a\end{array}$ & $\begin{array}{l}93.55 \pm 2.64 \\
\text { a }\end{array}$ & $\begin{array}{l}1.18 \pm 0.13 \\
\mathrm{a}\end{array}$ & 1 & $a^{86 \pm 4.01}$ \\
\hline 70 & $42.27 \pm 0.84 \quad$ b & $\begin{array}{l}62 \pm 3.75 \\
\mathbf{b}\end{array}$ & $\begin{array}{l}67.23 \pm 2.10 \\
\mathbf{b}\end{array}$ & $\begin{array}{l}1.4 \pm 0.08 \\
\mathrm{a}\end{array}$ & 1 & $\mathbf{b}^{42 \pm 3.75}$ \\
\hline 100 & $44.41 \pm 0.50 \mathrm{ab}$ & $\begin{array}{l}54 \pm 4.01 \\
\text { bc }\end{array}$ & $\begin{array}{l}62.00 \pm 3.27 \\
\mathbf{b}\end{array}$ & $\begin{array}{l}1.6 \pm 0.09 \\
\mathbf{a}\end{array}$ & 1 & $\mathbf{b}^{34 \pm 4.01}$ \\
\hline 125 & $46.26 \pm 0.88 \mathrm{a}$ & $38 \pm 3.75 c$ & $\begin{array}{l}58.66 \pm 3.75 \\
\text { b }\end{array}$ & $\begin{array}{l}1.8 \pm 0.18 \\
\mathbf{a}\end{array}$ & 1 & $c^{22 \pm 2.00}$ \\
\hline LSD 0.05 & 2.16 & 11.41 & 8.44 & 0.47 & & 10.38 \\
\hline
\end{tabular}

*Means followed by the same letter in each column (small letters) represent that are not significantly different at $(\mathrm{p}<0.05)$

*The progeny among $\mathrm{F}_{1}$ females of the greater wax moth, Galleria mellonella descending of the irradiated parental females as full-grown pupae

There was a negative correlation between the percentage of pupation and the increase of doses. The percentage of pupation significantly decrease to 62,54 and $38 \%$ at the three doses 70, 100 and 125 Gy respectively, compared to $92 \%$ for control treatment while, the parental females which irradiated with the dose 150 Gy did not give any progeny (Table 3).

The percentage of the adult emergence of the $F_{1}$ generation ( $F_{1}$ females) was significantly decreased at all treatments. It decreases to $67.23,62.00$ and $58.66 \%$ of the three doses 70, 100 and 125 Gy, respectively, compared to $93.55 \%$ for the control treatment (Table 3).

Additionally, the percentage of larvae that survived to the adult stage (Table 2) was significantly decreased with the dose increase. The percentage of survival was decreased to 42,34 and $22 \%$ at the three doses 70 , 100 and 125 Gy, respectively, compared to $86 \%$ for the control treatment.

Table 3 also, displays that the average sex ratio was increased with the dose increase. It was increased to $1.40,1.60$ and 1.80 at the three doses 70,100 and 125 Gy, respectively, compared to 1.18 for the control treatment

The combined effect of gamma irradiation and the entomopathogenic fungi on some biological aspects of the Greater wax moth, Galleria mellonella

Table 4 demonstrates the effect of gamma irradiation combined with the $\mathrm{LC}_{50}$ of the entomopathogenic fungi; $\boldsymbol{B}$. bassiana and $\boldsymbol{M}$. anisopliae on some biological aspects of $\boldsymbol{G}$. mellonella descending of the irradiated parental males.

Table 4 Effect of gamma irradiation combined with the $\mathrm{LC}_{50}$ of the entomopathogenic fungi on some biological aspects 


\begin{tabular}{|c|c|c|c|c|c|c|c|}
\hline \multirow{2}{*}{$\begin{array}{c}\text { Radiation } \\
\text { Doses } \\
\text { (Gy) }\end{array}$} & \multirow[b]{2}{*}{ Fungi } & \multirow{2}{*}{$\begin{array}{c}\text { Average } \\
\text { Larval and } \\
\text { pupal } \\
\text { Period / day } \\
\quad \pm \text { SE }\end{array}$} & \multirow{2}{*}{$\begin{array}{c}\% \\
\text { Pupation } \\
\pm \mathrm{SE}\end{array}$} & \multirow{2}{*}{$\begin{array}{c}\% \\
\text { Emergence } \\
\pm \mathrm{SE}\end{array}$} & \multicolumn{2}{|c|}{ Sex ratio } & \multirow{2}{*}{$\begin{array}{c}\text { \%Survival } \\
\text { 土SE }\end{array}$} \\
\hline & & & & & $\begin{array}{l}\text { Male } \\
\pm \mathrm{SE}\end{array}$ & Female & \\
\hline Control & - & $36.22 \pm 0.58$ & $\begin{array}{c}80 \pm 3.17 \\
a\end{array}$ & $95.00 \pm 03.07 \mathbf{a}$ & $\begin{array}{c}1.13 \pm 0.11 \\
\mathbf{a}\end{array}$ & $\begin{array}{l}1 \\
1\end{array}$ & $\begin{array}{l}76 \pm 4.01 \\
\mathrm{a}\end{array}$ \\
\hline \multirow[t]{2}{*}{$70 \mathrm{~Gy}$} & B.bassiana & $\begin{array}{c}43.55 \pm 0.29 \\
\mathbf{c}\end{array}$ & $\begin{array}{c}42 \pm 2.00 \\
\text { bc }\end{array}$ & $71.00 \pm 05.33 \mathbf{b}$ & $\begin{array}{c}1.40 \pm 0.48 \\
\mathrm{a}\end{array}$ & 1 & $\begin{array}{l}30 \pm 3.17 \\
\text { bc }\end{array}$ \\
\hline & P.lilacinus & $42.14 \pm 0.41$ & $\begin{array}{c}50 \pm 3.17 \\
\text { b }\end{array}$ & $75.66 \pm 04.14 \mathbf{b}$ & $\begin{array}{l}1.33 \pm \\
0.27 \mathbf{a}\end{array}$ & 1 & $\begin{array}{l}38 \pm 3.75 \\
\mathbf{b}\end{array}$ \\
\hline \multirow[t]{2}{*}{$100 \mathrm{~Gy}$} & B.bassiana & $\begin{array}{c}46.33 \pm 0.39 \\
\mathbf{b}\end{array}$ & $\begin{array}{c}30 \pm 4.48 \\
\mathrm{de}\end{array}$ & $63.33 \pm 05.66 \mathrm{~b}$ & $\begin{array}{c}1.60 \pm 0.24 \\
\mathrm{a}\end{array}$ & 1 & $\begin{array}{l}20 \pm 4.48 \\
\mathbf{c}\end{array}$ \\
\hline & P.lilacinus & $\underset{\mathrm{b}}{45.21 \pm 0.44}$ & $\begin{array}{c}38 \pm 2.00 \\
\text { cd }\end{array}$ & $68.33 \pm 04.87 \mathrm{~b}$ & $\begin{array}{c}1.30 \pm 0.30 \\
\mathrm{a}\end{array}$ & 1 & $\begin{array}{l}26 \pm 2.45 \\
\text { bc }\end{array}$ \\
\hline \multirow[t]{2}{*}{$125 \mathrm{~Gy}$} & B.bassiana & $\begin{array}{c}48.10 \pm 0.34 \\
\mathbf{a}\end{array}$ & $\underset{\mathbf{e}}{22 \pm 2.00}$ & $70.00 \pm \frac{\mathbf{b}}{\mathrm{b}} 12.28$ & $\begin{array}{l}1.00 \pm \\
0.31 \mathbf{a}\end{array}$ & 1 & $16 \pm 2.45$ \\
\hline & P.lilacinus & $\underset{\mathrm{b}}{46.63 \pm 0.32}$ & $\begin{array}{c}28 \pm 2.00 \\
\mathrm{e}\end{array}$ & $63.33 \pm 02.98 \mathbf{b}$ & $\begin{array}{c}1.20 \pm 0.20 \\
\mathbf{a}\end{array}$ & 1 & $\begin{array}{l}18 \pm 2.00 \\
\mathbf{c}\end{array}$ \\
\hline LSD & & 1.20 & 8.19 & 18.04 & 0.904 & & 10.15 \\
\hline
\end{tabular}

*Means followed by the same letter in each column represent that are not significantly different at $(p<0.05)$

\section{* The insects of $G$. mellonella resulted from irradiated parental males}

Also, Table 4 shows that the mean of larval and pupal periods were significantly increased with increasing the irradiation dose. It highly significantly increased to 43.55, 46.33and 48.10 days for $\boldsymbol{B}$. bassiana combined with the doses 70,100 and 125 Gy respectively, compared to 36.22 days in the control treatment. Also, it significantly increased to $42.14,45.21$ and 46.63 days for $\boldsymbol{P}$. lilacinus combined with the same previous irradiation doses, respectively.

As Shown from the previous data given in Table 4, the percentage of pupation was significantly decreased with increasing the irradiation dose and more decreases at $\boldsymbol{B}$. bassiana than at $\boldsymbol{P}$. lilacinus treatments. It significantly decreased to 42,30 and $22 \%$ for $\boldsymbol{B}$. bassiana when combined with the doses 70, 100 and 125 Gy respectively, compared to $80 \%$ in the control treatment while, it significantly decreases to 50,38 and $28 \%$ for $\boldsymbol{P}$. lilacinus combined with the same previous irradiation doses, respectively.

The percentage of adult emergence was significantly reduced to $71,63.33$ and $70 \%$ for $\boldsymbol{B}$. bassiana combined with the doses 70,100 and 125 Gy respectively, compared to 95\% in the control treatment Also, it significantly reduced to 75, 70 and $63.33 \%$ for $\boldsymbol{P}$. lilacinus combined with the same previous irradiation doses, respectively (Table 4).

Also, data in Table 4 shows that the sex ratio was in favour of males for $\boldsymbol{B}$. bassiana combined with the doses 70 and, 100 Gy (1.4 and 1.6, respectively), but was $1: 1$ at the dose rate 125 Gy compared to 1.1:1.0 at the 
control treatment. Also, it increased to 1.33 and 1.30 and 1.20 for $\boldsymbol{P}$. lilacinus treatment combined with the same previous irradiation doses, respectively.

Additionally, Table 4 demonstrates that the percentage of survival decreased with increasing the irradiation dose. It was significantly decreased to 30, 20 and $16 \%$ for $\boldsymbol{B}$. bassiana combined with the doses 70, 100 and 125 Gy respectively, compared to $76 \%$ in the control treatment Also, it significantly reduced to 38, 26 and $18 \%$ for $\boldsymbol{P}$. lilacinus treatment combined with the same previous irradiation doses, respectively.

Table 5 indicates that the effect of gamma irradiation combined with the $\left(\mathrm{LC}_{50}\right)$ of the entomopathogenic fungi; $\boldsymbol{B}$. bassiana and $\boldsymbol{P}$. lilacinus on some biological aspects of $G$. mellonella descending of the irradiated parental females.

The mean larval and pupal periods were significantly increased with the increasing irradiation dose. It highly significantly increased to $44.73,47.56$ and 48.70 days at 70,100 and 125 Gy doses combined with $\boldsymbol{B}$. bassiana compared to 36.22 days in the control treatment. Also, it significantly increased to 43.27, 45.16 and 47.40 days at 70,100 and 125 Gy, respectively, combined with $\boldsymbol{P}$. lilacinus compared to 36.22 days in the control treatment.

Table 5 Effect of gamma irradiation combined with the $\left(\mathrm{LC}_{50}\right)$ of the entomopathogenic fungi on some biological aspects

\begin{tabular}{|c|c|c|c|c|c|c|c|}
\hline \multirow{2}{*}{$\begin{array}{c}\text { Radiation } \\
\text { Dose } \\
\text { (Gy) }\end{array}$} & \multirow[b]{2}{*}{ Fungi } & \multirow{2}{*}{$\begin{array}{l}\text { Mean of } \\
\text { Larval and } \\
\text { pupal } \\
\begin{array}{c}\text { Period / } \\
\text { day } \\
\pm S E\end{array}\end{array}$} & \multirow{2}{*}{$\begin{array}{c}\% \\
\text { Pupation } \\
\pm \text { SE }\end{array}$} & \multirow{2}{*}{$\begin{array}{c}\% \\
\text { Emergence } \\
\pm \mathrm{SE}\end{array}$} & \multicolumn{2}{|c|}{ Sex ratio } & \multirow{2}{*}{$\begin{array}{c}\% \\
\text { Survival } \\
\pm \mathrm{SE}\end{array}$} \\
\hline & & & & & $\begin{array}{l}\text { Male } \\
\pm \mathrm{SE}\end{array}$ & Female & \\
\hline $\begin{array}{c}\text { Control } \\
\text { (0) }\end{array}$ & - & $\begin{array}{l}36.22 \pm \\
0.58 \mathrm{~d}\end{array}$ & $\begin{array}{c}80 \pm \\
3.17 \mathrm{a}\end{array}$ & $95.00 \pm 03.07 \mathrm{a}$ & $1.1 \pm 0.11 \mathrm{a}$ & 1 & $\begin{array}{l}76 \pm 4.01 \\
\mathbf{a}\end{array}$ \\
\hline \multirow[t]{2}{*}{$70 \mathrm{~Gy}$} & B.bassiana & $\begin{array}{c}44.73 \pm 0.43 \\
\text { b }\end{array}$ & $\begin{array}{l}36 \pm 4.01 \\
\text { c }\end{array}$ & $64.33 \pm 08.18 \mathbf{a}$ & $1.5 \pm 0.44 \quad \mathrm{a}$ & 1 & $\begin{array}{l}24 \pm 5.11 \\
\text { bc }\end{array}$ \\
\hline & P.lilacinus & $43.27 \pm 0.62$ & $\begin{array}{l}46 \pm 2.45 \\
\text { b }\end{array}$ & $74.00 \pm 03.68 \mathrm{a}$ & $1.7 \pm 0.43 \mathrm{a}$ & 1 & $\begin{array}{l}34 \pm 2.45 \\
\text { b }\end{array}$ \\
\hline \multirow[t]{2}{*}{$100 \mathrm{~Gy}$} & B.bassiana & $\begin{array}{c}47.56 \pm 0.37 \\
\mathbf{a}\end{array}$ & $\begin{array}{l}22 \pm 2.00 \\
\text { d }\end{array}$ & $73.33 \pm 11.33 \mathrm{a}$ & $1.0 \pm 0.31 \quad a$ & 1 & $\begin{array}{l}16 \pm 2.45 \\
\text { c }\end{array}$ \\
\hline & P.lilacinus & $\underset{\mathbf{b}}{45.16 \pm 0.73}$ & $\begin{array}{l}26 \pm 4.01 \\
\text { d }\end{array}$ & $65.00 \pm 10.02 \mathbf{a}$ & $1.2 \pm 0.37 \quad \mathbf{a}$ & 1 & $\begin{array}{l}18 \pm 4.91 \\
\text { C }\end{array}$ \\
\hline \multirow[t]{2}{*}{$125 \mathrm{~Gy}$} & B.bassiana & $\begin{array}{c}48.70 \pm 0.34 \\
\mathbf{a}\end{array}$ & $\begin{array}{l}16 \pm 2.45 \\
\text { d }\end{array}$ & $60.00 \pm 18.75 \mathrm{a}$ & $0.6 \pm 0.40 \mathrm{a}$ & 1 & $\begin{array}{l}10 \pm 3.17 \\
\mathbf{c}\end{array}$ \\
\hline & P.lilacinus & $\begin{array}{c}47.40 \pm 0.18 \\
\mathrm{a}\end{array}$ & $\begin{array}{l}20 \pm 3.17 \\
\text { d }\end{array}$ & $53.00 \pm 16.20 \mathrm{a}$ & $\begin{array}{c}0.8 \pm 0.37 \\
\mathbf{a}\end{array}$ & 1 & $\begin{array}{l}14 \pm 3.75 \\
\text { C }\end{array}$ \\
\hline LSD & & 1.43 & 9.02 & 33.36 & 1.06 & & 11.05 \\
\hline
\end{tabular}

*Means followed by the same letter in each column represent that are not significantly different at $(p<0.05)$

*The insects of G. mellonella in this Table descending of the irradiated parental females 
Table 5 shows that the percentage of pupation was significantly decreased with the increasing irradiation dose. It significantly decreases to 36,22 and $16 \%$ with the three doses 70, 100 and 125 Gy combined with $\boldsymbol{B}$. bassiana respectively, compared to $80 \%$ in the control treatment. Also, it significantly decreased to 46, 26 and $20 \%$ with the three doses 70,100 and 125 Gy combined with $\boldsymbol{P}$. lilacinus respectively.

Also, data in Table 5 shows that the sex ratio was in favour of males at the two doses 70 and 100 Gy combined with $\boldsymbol{B}$. bassiana (1.5 and 1.0 , respectively). While highly reduced to 0.6 at the dose 125 Gy compared to 1.1 in the control treatment. Also, it increased to 1.7 and 1.2 at the two doses 70 and 100 Gy combined with $\boldsymbol{P}$. lilaceous, respectively. While, at the dose 125 Gy it reduced to 0.8 .

Furthermore, Table 5 demonstrates that the percentage of adult survival decreases with the increasing the irradiation dose and more decreases in $\boldsymbol{B}$. bassiana than in $\boldsymbol{P}$. lilacinus. It was significantly decreased to 24,16 and $10 \%$ at the three doses 70,100 and 125 Gy combined with $\boldsymbol{B}$. bassiana, respectively, compared to $76 \%$ in the control treatment. While, it significantly reduces to 34,18 and $14 \%$ at the three doses 70, 100 and 125 Gy combined with $\boldsymbol{P}$. lilacinus, respectively.

\section{Discussion}

The biological activity (larval and pupal period, pupation, adult emergence, sex ratio and survival) of $2^{\text {nd }}$ instar larvae of G. mellonella treated with $\mathrm{LC}_{50}$ of $\boldsymbol{B}$. bassiana and $\boldsymbol{P}$. lilacinus has been studied. The results obtained indicated that the $\mathrm{LC}_{50}$ of entomopathogenic fungi caused a significant increase in the larval and pupal period as compared to the control. These results agree with Abd El- Ghany et al. 2012 recognized that the crude extracts of isolated fungi were screened against G. mellonella. applied different fungal crude extracts of isolates achieved variable results on both larval and adult mortality percentages. The effect of crude extracts of Beauveria bassiana (Siwa and El- Farafra isolate) giving total death percentages (82.48, and $74.22 \%$ respectively) to $\mathbf{G}$. mellonella larvae comparing with the control treatment $0 \%$. The results exhibited significant effects of $\boldsymbol{B}$. bassiana (El-Farafra and Siwa Oasis isolates) against $\mathbf{G}$. mellonella (larval and pupal weights). The \% of larvae death increased with increasing the concentration of crude extract of $\boldsymbol{B}$. bassiana (ElFarafra and Siwa isolates). Also pupal death percentage of $\mathbf{G}$. mellonella increased while adult emergence decreased with increasing concentration of crude extract of El-Farafra and Siwa isolates of B. bassiana. Abd EL-Wahed 2011 and Ibrahim et al. 2016 who found that the $L C_{50}\left(10^{8}\right.$ conidia $\left./ \mathrm{ml}\right)$ of the entomopathogenic fungi, $\boldsymbol{B}$. bassiana and $\boldsymbol{M}$. anisopliae prolonged the larval and pupal period of $\boldsymbol{A}$. ipsilon. Likewise, Kaur et al. $\mathbf{2 0 1 1}$ found that the $\boldsymbol{B}$. bassiana significantly reduced the larval period of $\boldsymbol{S}$. litura and this reduction was recorded in second and fourth instar treated larvae. Moreover, the $\mathrm{LC}_{50}$ of $B$. bassiana and $\boldsymbol{P}$. lilacinus reduced pupation, adult emergence and the percent survival of $\boldsymbol{G}$. mellonella. Similarly, the present investigation also, agreement with El-Sinary and Rizk 2007 who found $\boldsymbol{B}$. bassiana at conidial concentration $10^{8}$ conidia/ml reduce the pupation and the adult emergence of $\mathbf{G}$. mellonella to 20 and $13.33 \%$, respectively. Kannan et al. 2008 found that Metarhizium anisopliae at the highest conidial concentration $\left(10^{8}\right)$ significantly reduced the emergence of Anopheles stephensi to $40 \%$. In addition, Malarvannan et al. 2010 found that the $\boldsymbol{B}$. bassiana at spore concentration $2.4 \times 10^{7}$ and $2.4 \times 10^{4}$ conidia/ml caused the least pupation and adult emergence of $S$. litura, respectively. While, Abd EL-Wahed 2011 found that the LC $_{50}\left(10^{8}\right.$ conidia $\left./ \mathrm{ml}\right)$ of the entomopathogenic fungi, $\boldsymbol{B}$. bassiana and $\boldsymbol{M}$. anisopliae reduce the adult emergence of $\boldsymbol{A}$. ipsilon to 78.7 and $80.9 \%$, respectively. Kaur et al. 2011 also, observed a fewer number of adults (15.56-72.02\%) emerged when larvae of $S$. litura treated with the entomopathogenic fungi, $\boldsymbol{B}$. bassiana. Our results showed that the sex ratio was affected, with the fungal treatments, which was in favor of the male. These findings are in agreement with those found by with El-Sinary and Rizk 2007 who observed male ratio was greater than the female ratio when the $4^{\text {th }}$ instar larvae of $\mathbf{G}$. mellonella treated with B. bassiana.

These results were in agreement with LaChance et al. 1973 who reported that the survival to the adult stage of $F_{1}$ larvae of pink bollworm were significantly reduced at all doses and the sex ratio among emerging $F_{1}$ adults was also skewed in favor of males and more males were obtained when $\mathrm{P}_{1}$ males were treated with the dose of $50 \mathrm{~Gy}$ and above. El- Kady et 
al. 1983 also, found that the adult emergence was reduced as the radiation dose increased. Similarly, Carpenter et al. 1987 reported on fall armyworm when irradiated $P_{1}$ adults with the dose 100 Gy. Besides, Makee and Saour 1997 exposed the adult male Phthorimaea operculella to different doses of gamma irradiation (100, 150, and $200 \mathrm{~Gy})$ he found that the mean developmental time and the percentage mortality of the $F_{1}$ progeny increased at each examined dose Moreover, the sex ratio of the $\mathrm{F}_{1}$ progeny was skewed in favor of the males. Both Ramesh et al. 2002 on Spodoptera litura and Hofmeyr et al. 2005 on Cryptophlebia leucotreta reported that sex ratio skewed in favor of males. On the other hand, Carpenter et al. 2001 did not observe a skewed sex ratio in favor of male offspring for the Cactoblastis cactorum $\mathrm{F}_{1}$ adults.

The effect of different doses of gamma irradiation (70,100 and 125Gy) in combination with the $\mathrm{LC}_{50}$ of the entomopathogenic fungi tested, $\boldsymbol{B}$. bassiana and P.lilacinus against the $2^{\text {nd }}$ instar larvae of $\boldsymbol{G}$. mellonella descending of the irradiated parental males mated with unirradiated females or unirradiated males mated with the irradiated females on some biological aspects were examined. Our results showed that the combined effect prolonged the larval and pupal duration; reduced the percentage of pupation, adult emergence, and survival. The sex ratio of the $F_{1}$ generation also declined more in favor of males.

The present study indicated that the combined effect of the entomopathogenic fungi and gamma irradiation-induced more remarkable effects as compared to the entomopathogenic fungi or gamma irradiation of each them alone. Our results are following El-Sinary and Rizk 2007 using $\boldsymbol{B}$. bassiana at $10^{4}$ and $10^{8}$ spores / $\mathrm{ml}$ combined with different doses of gamma irradiation $(50,100$ and 150$)$ against the $4^{\text {th }}$ instar larvae of the greater wax moth, $\mathbf{G}$. melonella, the efficiency of B. bassiana increased, especially when the gamma irradiation dose was increased, where no adults were produced with both the fungal concentrations and 150 Gy gamma irradiation dose. Abd EL-Wahed 2011 also, showed that the LC 50 $\left(10^{8}\right)$ of the two entomopathogenic fungi; $\boldsymbol{B}$. bassiana and $\boldsymbol{M}$. anisopliae in combined with the $\mathrm{LD}_{50}(72 \mathrm{~Gy})$ of gamma irradiation against the $2^{\text {nd }}$ instar larvae of $\boldsymbol{A}$. ipsilon significantly increased the larval and pupal period and decreased the percentage adult emergence, of $\boldsymbol{A}$. ipsilon. Hussein et al.2018 indicated that the gamma irradiation increased the pathogenicity of the fungi against the tested larvae. The combination between the two control tools may provide satisfactory control of the insect-pest, especially, in the storage.

\section{Conclusions}

In general, the results indicated that females were more radiosensitive to gamma irradiation than males. The $F_{1}$ progeny resulting from the irradiated full-grown male pupae was more sterile than the irradiated $\mathrm{P}_{1}$ males and the $\mathrm{F}_{1}$ males were usually more sterile than the $F_{1}$ females. The entomopathogenic fungi, $\boldsymbol{B}$. bassiana and $\boldsymbol{P}$. lilacinus were the most virulent isolates causing the highest adult longevity against $2^{\text {nd }}$ instar larvae of Galleria mellonella and had the lowest $\mathrm{LC}_{50}$ values. Full-grown male and female pupae irradiated with different doses of gamma irradiation $(70,100,125$ and 150 Gy) showed delayed effects on the different biological aspects of $\mathbf{G}$. mellonella females were more radiosensitive than males. The sterilizing dose for males was above $150 \mathrm{~Gy}$, while the sterilizing dose for females was $150 \mathrm{~Gy}$.

The second instar larvae of Galleria mellonella descending of the irradiated parental male or female pupae with 70,100 and 125 Gy then treated with the $\mathrm{LC}_{50}$ of $\boldsymbol{B}$. bassiana and $\boldsymbol{P}$. lilacinus adversely affected on the different biological aspects. The combined treatment was greater than either, in the case of fungal or irradiation treatment alone.

\section{Declarations}

\section{Ethics approval and consent to participate}


The authors declare that they have ethics approval and consent to participate.

\section{Consent for publication}

The authors consent for publication.

\section{Availability of data and materials}

Data supporting the conclusions of this article are presented in the main Manuscript.

\section{Competing interests}

The authors declare that they have no competing interests.

\section{Funding}

No funding

\section{Authors' contributions}

The Manuscript writing was done by all authors. HF contributed writing and final review, S M set the basic ideas for the manuscript, MAS revised and corrected, AAMI developed and designed the biological control experiments, and OEAE designed, wrote and analyzed the tables statistically.reference settings were done by all authors. Then, final manuscript was read and approved by all authors. All authors read and approved the final manuscript.

\section{Acknowledgments}

Not applicable

\section{References}

Abd EL-Wahed AGA (2011) Combined effect of gamma radiation and some fungal control agents on the greasy cut-worm, Agrotis ipsilon (Huf.) (Doctoral dissertation, Faculty of Science, Al-Azhar University).

Caron DM (1992) Wax moth. American Bee Journal, 132 (10):647-649.

Carpenter JE, Bloem S, Bloem KA (2001) Inherited sterility in Cactoblastis cactorum (Lepidoptera: Pyralidae). Florida Entomologist 84: 537- 542.

Carpenter JE, Young JR, Sparks AN, Cromroy HL, Chowdhury MA(1987) Corn earworm (Lepidoptera: Noctuidae): effects of substerilizing doses of radiation and inherited sterility on reproduction. J. economic entomology, 80(2): 483-489.

Chang CP, Hsieh FK (1992) Morphology and bionomics of Galleria mellonella. Chinian J Entomology, m12 (2):121-129.

El-kady E, ASalem YS, Hekal AM (1983) Effect of Gamma Irradiation on Pupae of the Greasy Cutworm, Agrotis ipsilon (Hufn) (Lepidoptera: Noctuidae). Mededelingen-van-de-Faculteit-Landbouwwetenschappen,-Rijksuniversiteit- Gent, 48 (2):385-392.

El-khawaga OEAA (2017) Effect of Gamma Irradiation and Some Fungi on the Greater Wax Moth, Galleria Mellonella (L). M Sc thesis, Faculty of Science, Benha University.

El-Sinary NH, Rizk SA (2007) Entomopathogenic fungus, Beauveria bassiana (Bals) and gamma irradiation efficiency against the Greater Wax Moth, Galleria mellonella (L). American-Eurasian J Scientific Rese, 2 (1): 13- 18. 
Haewoon O, Young M, Chang Y (1995) Developing periods of damage patterns of combs by the wax moth, Galleria mellonella. J Apiculture Research, 10 (1):5-10.

Hofemeyr JH,Bloem S, Carpenter JE (2005) Radiation biology and inherited sterility in false codling moth (Lepidoptera: Tortricidae). International Atomic Energy Agency. Vienna (Austria); Food and Agriculture Organization of the United Nations, Rome (1ta1y) FAO/IAEA International conference on area-wide control of insect pests: Integrating the steri1e insect and related nuclear and other techniques. Book of extended synopses 386, pp 187.

Hussein FM,Thanaa MS, Samira EME,Mahmoud AES, Ahmed AMI,Ola EAAEE (2018) Effect of gamma irradiation and/or certain entomopathogenic fungi on the larval Mortality of Galleria mellonella L Egyptian Journal of Biological Pest Control 28(95):2-8.

Ibrahim AA, Mohamed HF, El- Naggar SEM, Swelim MA, Elkhawaga OE (2016) Isolation and Selection of Entomopathogenic Fungi as Biocontrol Agent against the Greater Wax Moth, Galleria mellonella L. (Lepidoptera: Pyralidae). Egyptian J Biological Pest Control, 26(2), 249-253.

Kannan SK, Murugan K, Kumar AN, Ramasubramanian N, Mathiyazhagan P (2008) Adulticidal effect of fungal pathogen, Metarhizium anisopliae on malarial vector Anopheles stephensi (Diptera: Culicidae). African J Biotechnology. 7(6): 838841.

Kaur S,Kaur HP, Kaur K, Kaur A (2011) Effect of different concentrations of Beauveria bassiana on development and reproductive potential of Spodoptera litura (Fabricius). J Biopest 4(2): 161-168.

LaChance LC, Robert AB, Richard RD (1973) Effect of low doses of gamma irradiation on reproduction of male pink bollworms and their $F_{1}$ progeny. Environ Entomol 4: 653-658.

Makee H, Saour G (1997) Inherited effects in F1 progeny of partially sterile male Phthorimaea operculella (Lepidoptera: Gelechiidae). J Economic Entomol. 90(5): 1097-1101.

Malarvannan S, Murali PD, Shanthakumar SP, Prabavathy VR, Nair S (2010) Laboratory evaluation of the entomopathogenic fungi, Beauveria bassiana gainst the tobacco caterpillar, Spodoptera litura Fabricius (Noctuidae: Lepidoptera). J Biopesticides, 3(1): 126-131.

Metwally HM, Hafez GA, Hussein MA, Hussein MA, Salem HA, Saleh MME (2012) Low cost artificial diet for rearing the greater wax moth, Galleria mellonella L.(Lepidoptera: Pyralidae) as a host for entomopathogenic nematodes. Egyptian J Biological Pest Control, 22(1): 15-17.

Mohamed HF, Sileem1 TM, El-Naggar SEM, Sweilem MA, Ibrahim AAM, El-khawaga OEAA (2018) Effect of gamma irradiation and/or certain entomopathogenic fungi on the larval Mortality of Galleria mellonella L Egyptian Journal of Biological Pest Control, 28:95

Nazir T, Abdul Basit, Abdul Hanan, Majeed MZ, Dewen Qiu (2019) In Vitro Pathogenicity of Some Entomopathogenic Fungal Strains against Green Peach Aphid Myzus persicae (Homoptera:Aphididae)Agronomy,9,7;doi: 10.3390/ agronomy 9010007

Ramesh K, Garg AK, Seth RK (2002) Interaction of substerilizing gamma radiation and thiodicarb treatment for management of the tobacco caterpillar, Spodoptera litura. Phytoparasitica 30(1): 7-17.

Steel RGD, Torrie JH (1980) "Principle and procedures of 2nded. (McGraw-Hill book Co., New York. 